\section{Michigan Technological 1 8 8 5 University}

Michigan Technological University Digital Commons @ Michigan Tech

Apr 21st, 1:45 PM - 1:54 PM

\title{
Session 2D Climate Change: Importance of the study of the seawater temperature of Paita and its impacts in the northern coast of Peru in 2017
}

Jefferson Stefan Llacsahuanga Pusma

Universidad de Piura

\section{Recommended Citation}

Stefan Llacsahuanga Pusma, Jefferson, "Session 2D Climate Change: Importance of the study of the seawater temperature of Paita and its impacts in the northern coast of Peru in 2017" (2021). Global Conference of the Youth Environmental Alliance in Higher Education. 51. 


\section{Climate change: Importance of the study of the seawater temperature of Paita and its impacts in the}

northern coast of Peru in 2017.

\section{Llacsahuanga Jefferson - Universidad De Piura}

Introduction

In the year 2017, the northern coast of Peru and the south of Ecuador were impacted by devastating rains and floods that affected a lot of people and destroyed infrastructure, due to the occurrence of a phenomenon " El Niño" coastal.

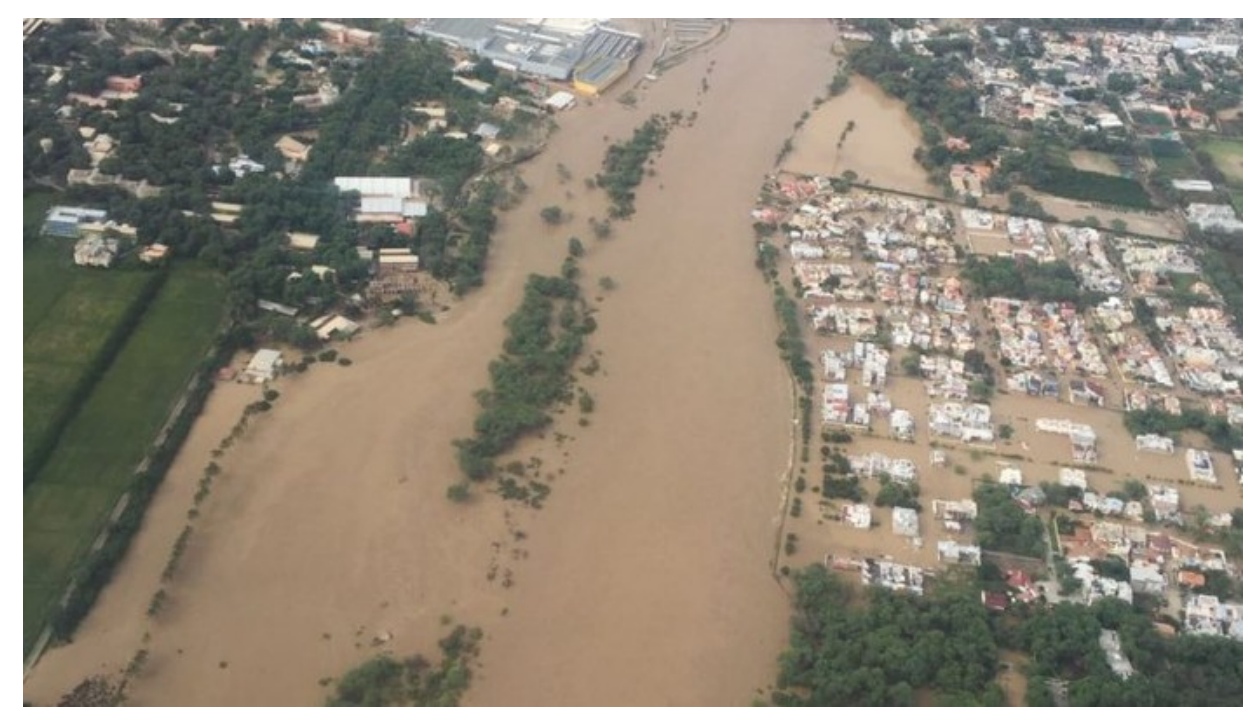

Figure.1The photo shows the flood due to the overflow of the Piura River.

\section{¿What is "El Niño"?}

"El Niño" (The Child) is a climatic phenomenon. It is related to the increase of seawater temperature (SST) in the equatorial pacific ocean. It is the main modulator of interannual climate variability throughout the world.

The "Coast El Niño" is the phenomenon that happens when seawater warming is only in the littoral zone of Peru and Ecuador, as a consequence torrential rains occur in the coastal area of these countries.

Figure 2 (right box) shows the anomaly of the seawater surface temperature (SST) for march 2017 during coastal "El Niño" of that year in the ocean area in Peru and Ecuador. The anomaly temperature was approximate $+3.5^{\circ} \mathrm{C}$ higher than the normal (left box). The central box shows the SST in march 2017.

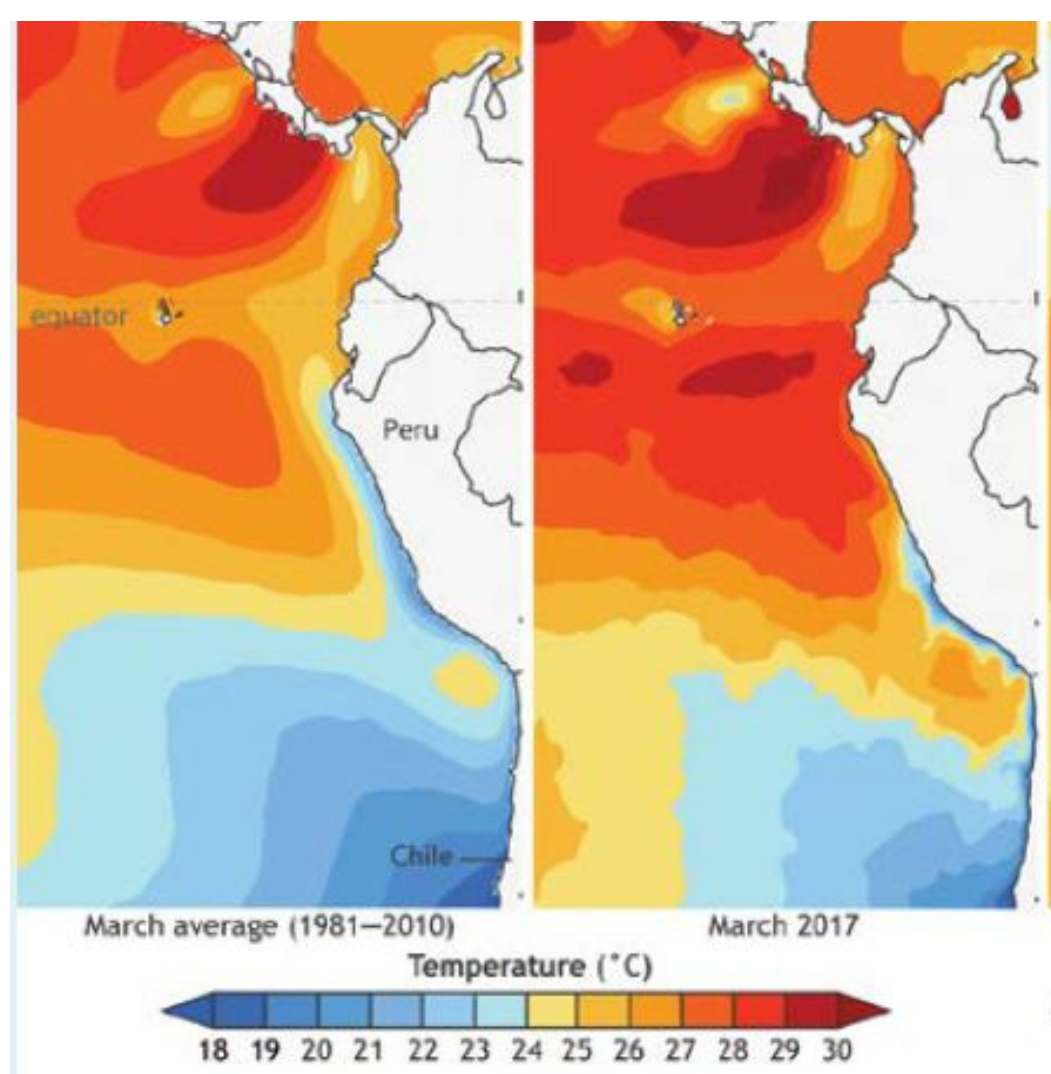

Figure.2 Sea surface normal temperature (1981-2010), march 2017 and anomaly 2017( NOAA,2017)

\section{Seawater temperature at Paita, Peru, in 2017}

The data of SST at Paita, Peru, in 2017 showed abnormal behavior in the three first months of that year. The SST, in this peruvian port, increased above the average during january, and keep in high values during february and march as show the figure 3 . The anomaly during this month was approximately $5^{\circ} \mathrm{C}$, being a peak nearly the maxim temperature registered.

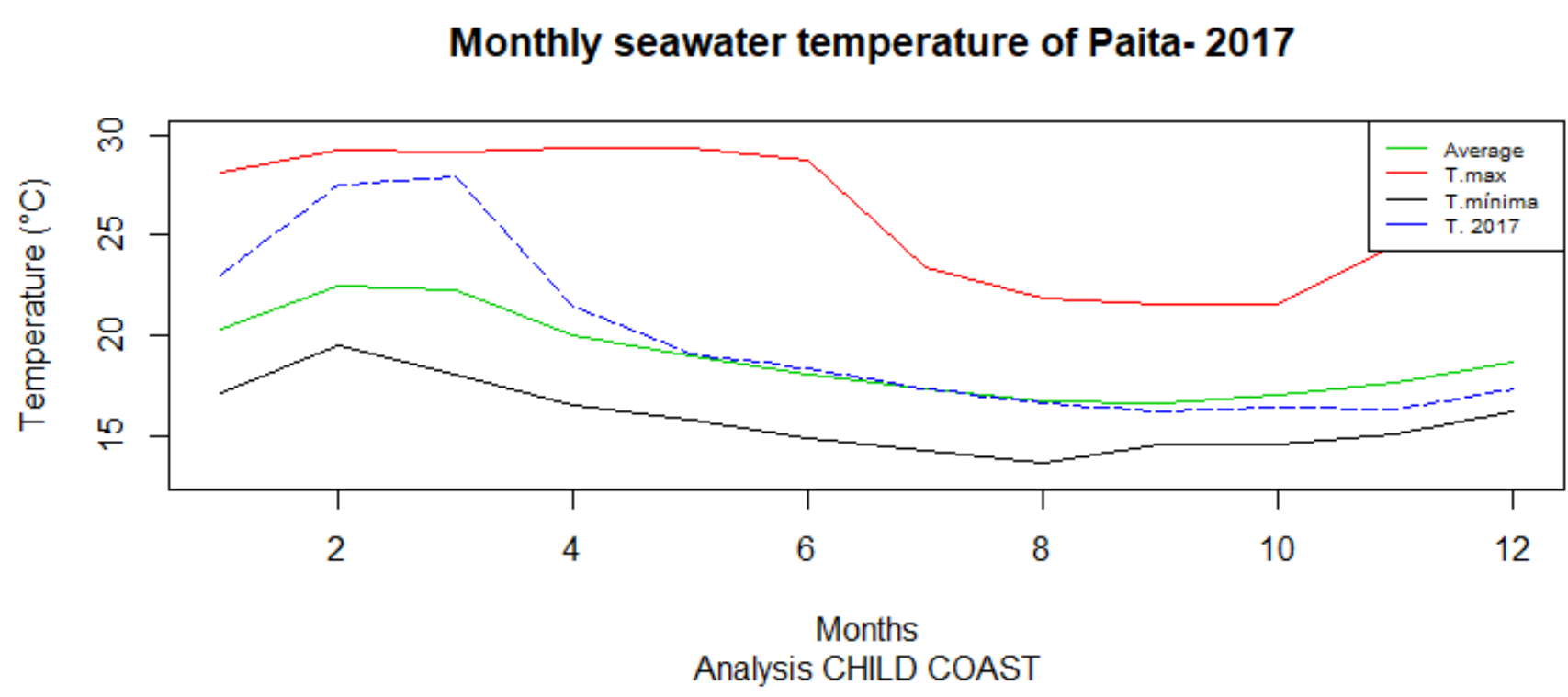

Figure.3 Graphic of own elaboration about the data seawater 2017.

\section{¿What were the impacts?}

The impacts of heavy rain in the northern coast of Peru were mainly in population and ecosystem. Economic activties as agriculture, fishing and transport were affecting.

Table.1Data about the analysis of impact in Peru.(INDECI 2017)

\begin{tabular}{ll|}
\hline Sector damage & \multicolumn{1}{c}{ Numbers } \\
\hline Demographic & $\begin{array}{l}114 \text { deaths and 1.08 million } \\
\text { of affected. }\end{array}$ \\
\hline Agriculture & 90 thousand hectares lost. \\
Transport & $\begin{array}{l}\text { 4931 Km of roads and } 881 \\
\text { bridges }\end{array}$ \\
infrastructure & $\begin{array}{l}\text { 3.9 Thousand million } \\
\text { dollars. }\end{array}$ \\
\hline Total losses &
\end{tabular}
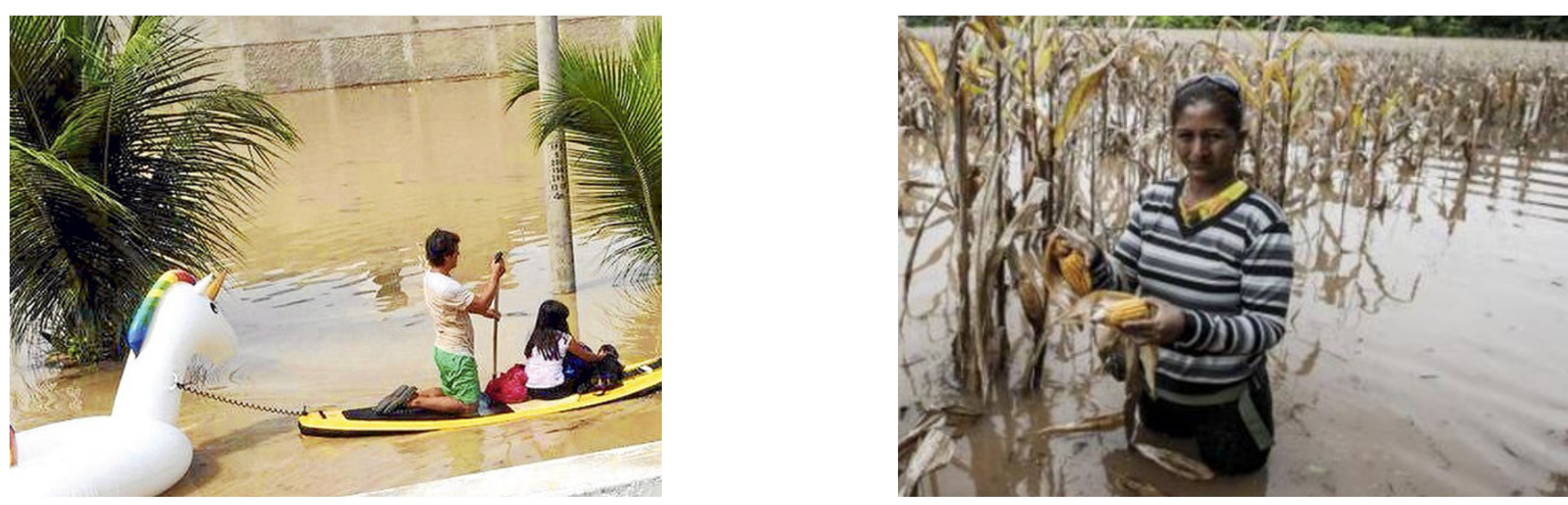

Figure.4 Photos are showing the impact of "El Niño" Coast in the northern coast Perú.

\section{Conclusions}

Monitoring of seawater temperature is important, for predict climatic anomalies to prevent floods on the coast of northern Peru and southern Ecuador.

An "El Niño" very strong category even can impact almost around the world. And as a consequence of the global warming estimate that "El Niño" could be of great magnitude.

As part of the development objectives, the action for climate has to encompass or contribute different politics and national strategies for reducing the consequences of these, in where the numbers indicate the great impact of natural disasters.

References:Venkatwswaran,K., MacClune,K. and Enríquez,M.F(2017). El Niño Costero: The 2017 floods in Peru. Zurich Flood Resilience Alliance. 